\title{
MEMBANGUN TEOLOGI PERTANIAN MELALUI PEMBACAAN LINTAS TEKSTUAL INJIL MATIUS DAN KOSMOLOGI JAWA
}

\author{
Firman Panjaitan \\ Sekolah Tinggi Teologi Tawangmangu \\ panjaitan.firman@gmail.com
}

\begin{abstract}
Today's agriculture often relies on pesticides, which cause soil damage and ecosystem imbalances. The use of pesticides is because humans do not feel part of nature. This article aims to explore the example of Jesus Christ as a farmer as written in the Gospel of Matthew and relate it to the cosmological wisdom of Javanese culture. The hope is to build a contextual agricultural theology that respects and maintains the harmony of natural life. The method used is cross-textual reading, which takes positive messages from two texts/contexts that are juxtaposed to construct a form of contextual theology. As a result, contextual agricultural theology emphasizes that farming is worship that encourages humans to preserve the universe with the realization that humans and nature are brothers and sisters created by God. Both must care and protect each other. In that unity, they find themselves united with God. The contextual agricultural theology only recommends organic farming as the right way of agriculture because this model will preserve the natural and human life.
\end{abstract}

Keywords: Jesus the Farmer, Contextual Theology, the Gospel of Matthew, Javanese Cosmology

\begin{abstract}
Abstrak. Dewasa ini pertanian yang dijalankan seringkali mengandalkan pestisida yang mengakibatkan kerusakan tanah dan ketidakseimbangan ekosistem. Ini disebabkan manusia tidak merasa sebagai bagian dari alam. Artikel ini bertujuan menggali keteladanan Yesus Kristus sebagai seorang petani seperti yang dituliskan dalam Injil Matius dan menghubungkannya dengan kearifan kosmologis budaya Jawa. Harapannya akan membangun sebuah teologi pertanian kontekstual yang menghargai dan menjaga keharmonisan hidup alam. Metode yang digunakan adalah pembacaan lintas tekstual, yaitu mengambil pesan positif dari dua teks/konteks yang disandingkan untuk membangun sebuah bentuk teologi yang kontekstual. Hasilnya, teologi pertanian kontekstual menekankan bahwa bertani adalah sebuah ibadah yang mendorong manusia untuk menjaga kelestarian alam semesta dengan kesadaran bahwa manusia dan alam adalah sesama saudara diciptakan oleh Tuhan. Keduanya harus saling menjaga dan melindungi. Di dalam kesatuan tersebut mereka menemukan diri mereka bersatu dengan Allah. Teologi pertanian kontekstual hanya merekomendasi pertanian organik sebagai cara bertani yang benar karena model ini akan menjaga kelestarian hidup alam dan manusia.
\end{abstract}

Kata kunci: Yesus sang Petani, Teologi Kontekstual, Injil Matius, Kosmologi Jawa

\section{PENDAHULUAN}

Pola pertanian di Indonesia dewasa ini didasarkan pada usaha peningkatan

hasil pertanian yang mengakibatkan perubahan dari pola pertanian tradisional ke 
pola pertanian industrial. Pola industrial sangat mengandalkan teknologi dengan tujuan untuk meningkatkan produktivitas pertanian sekaligus menurunkan biaya produksi. Sayangnya pola ini justru berdampak buruk terhadap tanah. Fadilah mengungkapkan bahwa penggunaan teknologi mengijinkan pemakaian pestisida dan pupuk kimia dalam jangka panjang dapat menghancurkan struktur tanah dan mengakibatkan tanah menjadi kering dan tandus (Fadillah 2019).

Pola pertanian yang tidak ramah terhadap lingkungan/alam seperti ini telah menggeser pola hubungan manusia dengan alam, sehingga prinsip dasar bahwa manusia merupakan bagian dari alam semesta mengalami perubahan drastis. Panjaitan berpendapat bahwa penggunaan teknologi pertanian yang telah terorganisasi berdampak pada penguasaan manusia terhadap alam semakin meningkat dan pada akhirnya akan merusak dan menghancurkan kehidupan alam semesta (Panjaitan 2011).

Gensichen menilai bahwa pola pertanian industrial akan melestarikan jarak antara manusia dengan alam dan ini berpotensi untuk menghancurkan kehidupan ekosistem dan habitat yang ada (Gensichen 2000), dan Andang menambahkan bahwa pola pertanian industrial ini telah menafikan dialog kehidupan dari seluruh unsur alam sesmesta, termasuk manusia, yang mengakibatkan kesatuan hubungan antara manusia dengan alam menjadi ternoda (Al Andang 1998).

Horrel menegaskan bahwa masalah ketiadaan dialog kehidupan antara manusia dan alam semakin diperparah oleh pandangan teologi tradisional yang melihat kisah penciptaan (Kej. 1-2) sebagai bentuk pelemahan kepekaan terhadap suara alam dalam menjawab persoalan-persoalan teologis secara keseluruhan 
(Horrel 2009) karena terlalu menekankan unsur antroposentrisme, akibatnya tercipta dualisme antara manusia dengan alam. Dalam pandangan Jr, situasi ini terjadi karena akibat konsep antroposentrisme yang menempatkan manusia sebagai mahkota penciptaan sehingga merasa diri berhak untuk berkuasa, menaklukkan bahkan mengeksploitasi alam demi kepentingannya sendiri (Jr. 1974). Hartati dan Natar menilai bahwa kondisi ini akan menjadi ancaman yang serius bagi seluruh kehidupan di muka bumi ini (Natar 2019; Hartati 2012).

Menurut Panjaitan dan Raphael, jika kisah penciptaan (Kej. 1-2) diperhatikan secara ekologis - teologis sebenarnya hendak menjelaskan bahwa Allah menempatkan manusia sebagai satu kesatuan dengan alam semesta, sebagai wujud kesatuan yang tidak terpisahkan (Panjaitan 2005; Raphael 2016). Oleh sebab itu, tambah Harun dan Raphael, upaya membangun dialog kehidupan dengan alam semesta menjadi hal yang sangat penting (Harun 2015) agar tercipta penyatuan diri manusia dengan alam semesta sekaligus mengembalikan manusia ke dalam hakikatnya sebagai bagian dari alam semesta. (Raphael 2016).

Menurut Dewi, ketidakramahan pola pertanian yang mengakibatkan timbulnya jarak antara manusia dengan alam juga melanggar sistem kehidupan yang dikembangkan oleh masyarakat Jawa yang memandang bahwa keutamaan seorang manusia senantiasa berada dalam kebersatuannya dengan alam (Dewi 2015). Terkait dengan hal terebut, Widijanto menegaskan bahwa jika manusia terpisah dari alam akan mengalami kematian karena kehidupan manusia sangat bergantung pada kerekatan hubungannya dengan alam semesta. (Widijanto 2018). 
Kajian artikel ini hendak menggali konsep teologi pertanian melalui pembacaan lintas tekstual mengenai pengajaran Yesus tentang konsep kesatuan manusia dengan alam melalui terapan pertanian yang dilakukan-Nya dalam Injil Matius dengan ajaran kosmologis budaya Jawa tentang kesatuan hubungan antara manusia dengan alam semesta.

\section{METODE PENELITIAN}

Metode yang digunakan dalam kajian ini adalah pembacaan lintas tekstual. Menurut Lee, metode ini mencoba memahami teks Alkitab dalam relasinya dengan teks budaya dan berupaya untuk menginterpenetrasi serta mengintegrasikan berita dari kedua teks tersebut. Metoda ini juga akan mengelaborasi perbandingan, perjumpaan, dan menciptakan simbiosis di antara dua teks yang berbeda, yaitu teks dari Alkitab dan teks dari budaya yang memiliki sifat religius, dan sebelum mengolah kedua teks dalam pembacaan lintas tekstual, terlebih dahulu kedua teks ditelaah dalam dirinya sendiri-sendiri dengan menggunakan format yang sesuai, yaitu menginterpretasi teks-teks Injil yang akan dipakai dan teks budaya. (Lee 1998).

Sebagai langkah akhir, penulis akan menggunakan metode deskriptif, yang menurut Brata merupakan bentuk metode yang bermaksud membuat pencandraan mengenai situasi-situasi dan kejadian-kejadian (Brata 2002) sehingga tercipta sebuah bentuk teologi kontekstual yang mencakup konteks kosmologi Jawa maupun teks Alkitab tentang teologi pertanian. 


\section{HASIL PENELITIAN}

Melalui pembacaan lintas tekstual antara peristiwa Yesus dalam Injil Matius dengan kosmologi Jawa mengenai hubungan antara Allah-manusia-alam, didapat pengertian bahwa teologi pertanian kontekstual adalah salah satu perspektif untuk melihat bahwa persoalan-persoalan yang menyangkut hubungan manusia dengan alam tidak melulu persoalan sosial, ekonomi atau ekologi semata, namun juga terkait dengan persoalan keagamaan. Dalam hal ini teologi pertanian kontekstual mendorong manusia untuk melihat dan menemukan Allah dalam tindakan mereka dalam mengupayakan kehidupan tumbuh-tumbuhan dan kesuburan tanah. Pertanian bukan sekadar sebuah tindakan jasmani belaka, melainkan merupakan aktivitas peribadatan guna memakmurkan dan menjaga kelestarian bumi, sebagai wujud dari ketundukan manusia kepada Allah. Melalui teologi pertanian kontekstual manusia menyatukan dirinya dengan Allah melalui kesatuan dengan alam semesta.

Baik Injil maupun kosmologi Jawa mengajarkan manusia untuk menjadi penanggung jawab utama dalam menjaga keberlangsungan kehidupan alam semesta. Manusia adalah bagian dari alam sehingga harus mengupayakan harmonisasi terhadap alam. Dalam ajaran mengenai pertanian, Yesus menegaskan bahwa bertani adalah tindakan yang memertahankan hubungan antara manusia dengan alam.

Dalam pertanian, manusia mengelola alam sekaligus menerima hasil dari alam, dan hubungan yang tercipta adalah saling memberi dan menjaga. Manusia 
mengelola dan menjaga alam melalui pertanian yang benar, dan alam pun menjaga kehidupan manusia dengan memberikan hasil pertanian yang baik.

Demikian juga dalam pemahaman kosmologis Jawa yang menegaskan bahwa harus memiliki kepekaan kosmik terhadap alam, sehingga manusia tidak pernah memandang dirinya terpisah dari alam karena merupakan bagian langsung dari kehidupan alam semesta ini. Tanggung jawab manusia adalah hidup bersatu dengan alam dengan cara menjaga kelestarian alam yang juga berarti menjaga kelangsungan kehidupan manusia itu sendiri. Alam dan manusia adalah dua pribadi yang saling menjaga dan melindungi.

Dengan demikian konsep teologi pertanian kontekstual yang dihasilkan melalui pembacaan lintas tekstual antara Injil dan budaya Jawa adalah sebuah upaya tindakan iman untuk mengembangkan bentuk pertanian yang selaras dengan alam. Teologi ini mempertimbangkan alam sebagai basis dari kehidupan. Upaya eksplorasi dalam bidang pertanian dimungkinkan sejuah menciptakan equilibrium (keseimbangan) atmosfir kehidupan semesta di mana manusia tidak lagi mengeksploitasi alam. Alam dipandang sebagai saudara bagi dirinya yang memiliki kesatuan hakiki, dan dalam kesatuan ini manusia dan alam pun mengalami kesatuan yang utuh dengan Allah.

Untuk menjaga harmonisasi manusia dan alam, teologi pertanian kontekstual menekankan bahwa manusia bukanlah 'tuan' bagi alam semesta, tetapi saudara yang saling menjaga, karena keduanya adalah hasil ciptaan Allah. Dengan demikian teologi pertanian kontekstual mendorong manusia untuk bertani secara ramah lingkungan agar terjaga kelestarian alam. Pertanian yang ramah 
lingkungan adalah pertanian yang menghargai kehidupan alam, tanpa ada keinginan merusak dengan menggunakan pestisida maupun pupuk kimia yang berpotensi menghancurkan kehidupan alam, dengan kata lain pertanian yang dikembangkan adalah pertanian organik.

\section{PEMBAHASAN}

\section{Hubungan Allah, Manusia, dan Alam dalam Kosmologi Jawa}

Endraswara mengungkapkan bahwa dalam budaya Jawa terdapat konsep Jumbuhing Kawula Gusti, yaitu pemahaman bahwa dunia dan seluruh isinya (termasuk manusia) berasal dan bertujuan kepada Yang Ilahi. Oleh karena itu antara Yang Ilahi dengan seluruh ciptaan adalah satu kesatuan yang tidak terpisahkan. Kesejatian hidup yang utama terletak pada pemahaman tentang kemanunggalan kawula (manusia dan alam semesta) dengan Gusti (Allah/Yang Ilahi). Inilah tujuan utama hidup manusia Jawa dan jika manusia Jawa sudah mencapai taraf tersebut, maka ia akan disebut sebagai 'manusia sejati' karena telah bersatu dengan Allah dan alam semesta (Endraswara 2018). Sehubungan dengan konsep tersebut, Suseno menambahkan bahwa manusia dapat menemukan jati dirinya secara utuh melalui alam semesta (Magnis-Suseno 1997). Secara khusus, tegas Endraswara, budaya Jawa mengajarkan bahwa manusia adalah pewujudnyataan langsung (mikroskosmos) dari keberadaan alam semesta (makrokosmos), sehingga keduanya tidak boleh saling menguasai satu sama lain (Endraswara 2018). 
Dalam pengajaran mengenai leluhur manusia, Akkeren melihat budaya Jawa mengajarkan bahwa manusia adalah keturunan langsung dari Dewa Wisnu dan Dewi Sri, di mana dalam perkembangan pemahaman selajutnya Dewi Sri ditampakkan wujud aslinya sebagai padi. (Akkeren 1970). Panjaitan berpendapat bahwa pengajaran ini hendak menegaskan bahwa padi dan manusia berasal dari nenek moyang ilahi yang sama, sehingga terdapat kesejajaran dan analogi antara siklus hidup padi dengan manusia dan keduanya diikat dalam sebuah relasi yang bersifat mistis, yaitu sebuah relasi yang menunjukkan kesatuan hubungan yang tidak terpisahkan sama sekali. (Panjaitan 2003). Relasi mistis padi dengan manusia menentukan kesatuan hidup dalam diri manusia, khususnya masyarakat Jawa. Bagi Akkeren, beras/padi, yang adalah buah hasil perkawinan ilahi, dipandang sebagai tanaman kehidupan firdaus sehingga beras/padi merupakan sumber kehidupan surgawi bagi manusia untuk dapat mempertahankan kehidupannya di alam semesta ini. (Akkeren 1970). Menurut Widijanto dari pandangan ini muncul pemahaman teologis yang mengungkapkan bahwa di dalam benih padi itu ada unsur ilahi, dan bila manusia memakan bulir-bulir padi maka manusia sedang memakan unsur ilahi yang mampu memberikan kehidupan dan menghidupi manusia. Ada kekuatan yang bersifat 'adi kodrati' dalam unsur tanaman padi. (Widijanto 2018).

Singgih berpendapat bahwa budaya Jawa, secara implisit, hendak mengajarkan bahwa Allah dapat dijumpai di dalam alam semesta, karena alam semesta merupakan wujud penampakan Allah (teofani) sekaligus sebagai bentuk simbolisasi dari kehadiran Allah secara nyata, namun perlu ditegaskan bahwa 
alam semesta tidaklah identik dengan Allah (Singgih 1999). Pengajaran ini menegaskan bahwa penampakkan Allah dalam diri alam semesta, yang diwakili oleh keberadaan bulir-bulir padi, mampu memberikan kehidupan bagi manusia, karena padi menjadi salah satu makanan pokok bagi manusia. Dengan demikian, tegas Takenaka, Allah bukanlah Allah yang jauh dan tidak terjangkau oleh manusia, melainkan selalu dekat dan bahkan bersedia untuk menyatu dengan manusia melalui bulir-bulir padi yang masuk ke dalam diri manusia dalam bentuk makanan (Takenaka 1986). Dalam pandangan Jawa, Vale dan Ituma mengatakan bahwa alam semesta adalah rumah bagi semua kehidupan, yang didalamnya mengambarkan kebersamaan hidup antar organisme-organisme dan lingkungan (Vale 1995), ini berarti setiap organisme hidup dalam saling ketergantungan .(Ituma 2013).

Vale menambahkan, sangat disayangkan kearifan budaya Jawa sangat bertentangan dengan fenomena yang terjadi sekarang. Fenomena sekarang menunjukkan bahwa dengan pengorganisasian ilmu pengetahuan, manusia membangun sistem pertanian dengan mengandalkan sistem monocropping (hanya menanam satu jenis tanaman saja) dan menjaga kesuburan tanah serta ketiadaan hama melalui penggunaan pupuk kimia dan pestisida. Tindakan ini mengakibatkan timbulnya irreversibilitas, yaitu ketidakmampuan flora dan fauna melakukan regenerasi akibat penghancuran ekosistem dan habitat oleh manusia. Irreversibilitas terjadi karena dalam kenyataannya pupuk kimia akan mengakibatkan struktur tanah terganggu dan akhirnya tanah mengalami kerusakan. Jika struktur tanah sudah rusak maka semua jenis/varietas tanaman 
tidak akan bisa hidup di atas tanah tersebut. (Vale 1995). Menurut Soemadi, penggunaan pestisida ini akan mengakibatkan rantai makanan di antara predator hama tanaman kehidupan terganggu dan menimbulkan timbunan sampah, hal ini merupakan ancaman langsung bagi kehidupan. Untuk melawan fenomena ini, budaya Jawa mengajak petani untuk 'mengistirahatkan' tanah pasca panen dengan cara mengganti jenis tanaman lain dengan tujuan agar struktur tanah akan terpelihara dengan baik, karena dengan perbedaan jenis tanaman maka kandungan zat makanan yang diserap bukan berasal dari dalam lapisan tanah yang sama dengan tanaman berikutnya. (Soemardi 2019).

\section{Pola Pertanian Yesus Menurut Injil Matius}

Injil Matius menggambarkan bahwa kehidupan Yesus berada di tengah masyarakat agraris. Hal ini bisa dilihat melalui penggambaran Yesus yang akrab dengan kehidupan pertanian. Ia tahu masa panen atau belum, sehingga perlu ada perencanaan untuk memanen entah itu dengan cara mengutus para pekerja untuk memanen atau pun mencari pekerja dalam memanen hasil pertanian yang ada. Ia juga tahu tentang metode dan alat-alat pertanian dalam perumpamaan untuk menjelaskan pokok-pokok ajaran-Nya (Mat. 9:37,38; Mat. 11:28-30). Oleh sebab itu setiap ajaran yang dilatarbelakangi bidang pertanian lebih mudah dimengerti oleh para pendengar-Nya yang memiliki latar belakang tradisi bertani. Karena itu, mereka memahami apa yang Yesus katakan dan Yesus pun tahu keseharian serta perasaan mereka dan mereka tergugah oleh ajaran-Nya (Mat. 7:28).

Dalam tulisannya mengenai The Parables of Jesus, Draper mengungkapkan bahwa Yesus sangat memahami dunia pertanian. Hal ini terbukti 
ketika Yesus sangat mengerti mengenai waktu untuk menabur dan mengenai upaya untuk menggemburkan tanah dan menyingkirkan lalang yang bisa mencekik tunas-tunas muda (Mat. 13:7). Di bagian lain, Yesus pun tahu kapan waktu untuk menuai yang ditandai dengan persiapan untuk memanen, mengumpulkan biji-bijian dan mengikatnya menjadi berkas-berkas, lalu menaruhnya di atas keledai atau gerobak dan kemudian dibawa ke lantai pengirikan di desa (Mat 3:12). Semua ini memunculkan spekulasi bahwa Yesus adalah seorang petani. (Draper 1987).

Di samping sebagai seorang petani, Hurtado menunjukkan bahwa Yesus pun belajar dari ayahnya tentang perdagangan (Mat. 6:3) dan perniagaan, karena Ia melihat bahwa ayah-Nya harus menjual sendiri hasil pertukangan (Mat. 13:55). (Hurtado 2011). Namun perlu dipahami, tegas Theissen, bahwa penduduk Nazareth sebenarnya mengandalkan hidup sebagai petani, karena pada jaman Yesus, 97\% tanah di Palestina digunakan untuk pertanian. Salah satu kota di Palestina, yaitu Nazareth, merupakan daerah dengan karakter pedesaan yang kuat. (Theissen 2005). Kenyataan ini menunjukkan bahwa Yesus tidak hanya belajar menjadi tukang kayu dan mendalami dunia perniagaan, tetapi Ia juga belajar dunia pertanian seperti yang dilakukan oleh masyarakat di sekitar-Nya. Menurut Hurtado, tidaklah mengherankan apabila Yesus sangat mengerti segala bentuk pekerjaan pertukangan, perniagaan, pertanian dan juga musim-musim yang mengikutinya. (Hurtado 2011). Bahkan Wijaya menuliskan bahwa di dalam Matius 25:31-46, Yesus dengan sengaja mengidentifikasikan diri-Nya sama 
dengan para petani dan buruh tani yang dipandang sebagai bagian terendah dari sistem masyarakat. (Wijaya 2011).

Pengetahuan mengenai dunia pertanian menjadi sebuah kekuatan yang dipakai oleh Yesus untuk menjelaskan tentang Kerajaan Surga dengan menggunakan perumpamaan mengenai dunia pertanian. Dalam Matius 13:1-23 dengan sangat gamblang Yesus menjelaskan bahwa firman Allah yang diberikan Allah kepada manusia itu digambarkan seperti seorang petani yang menabur benih ke atas tanah. Gambaran firman Allah sebagai benih yang ditabur menjadikan perikop ini dikenal dengan istilah 'Injil petani' yang menggugah manusia untuk melihat apakah dirinya seperti seorang petani yang mau menebarkan benih firman Allah kepada kehidupan. Bahkan melalui pemahaman 'Injil Petani' ini bisa diajukan pertanyaan reflektif, apakah sebenarnya para pengikut Yesus adalah juga seorang petani yang siap untuk menabur dan menuai benih Kerajaan Sorga?

Melalui tindakan dan pengajaran yang diberikan sesungguhnya Yesus sedang mengdentifikasi diri sebagai seorang manusia sejati yang terlibat dalam tindak kehidupan nyata. Melalui tindakan ini, tidaklah salah jika dikatakan bahwa Yesus adalah Immanuel, 'Allah menyertai kita' (Mat. 1:23), yang menunjukkan bahwa Allah tidaklah hidup terpisah dengan manusia, yang immanen. Sebutan Immanuel merupakan sebutan yang menekankan penyertaan dan keterlibatan Allah di dalam hidup manusia. Ini menunjukkan bahwa Allah berpihak pada manusia, sehingga manusia tidak layak untuk merasa gelisah dalam hidupnya, termasuk dalam masalah makanan/pangan. Melalui gelar ini, Yesus hendak mengajarkan manusia untuk senantiasa berharap kepada Allah, karena Allah pun 
sangat mengerti tentang kebutungan pangan manusia sekaligus sangat mengerti bagaimana mengupayakan agar pangan itu senantiasa tersedia bagi manusia. Di sinilah Allah, dalam Yesus, mengindentifikasikan diri-Nya sebagai seorang petani.

Pengidentifikasian Yesus terhadap seorang petani menunjukkan bahwa Yesus adalah pribadi yang selalu berpihak dan berada di lingkungan orang-orang miskin dan yang seringkali diabaikan. Ini juga merupakan tanda yang nyata dari pewujudnyataan janji Allah kepada kaum marginal yang selalu dijadikan skandal oleh para penguasa. Yesus menjadi bagian mereka yang tertindas serta dipinggirkan untuk melepaskan mereka dari ketertindasan sekaligus mengajarkan mereka untuk berperan aktif dalam menentukan hidup mereka. Oleh sebab itu, menurut Pieris, sebagai seorang petani Yesus mengajarkan mereka yang dipinggirkan ini untuk menguasai bidang pertanian dengan baik, sehingga melalui penguasaan tersebut mereka bisa mengupayakan kehidupan yang lebih baik dengan mengandalkan hasil-hasil pertanian yang mereka peroleh dari kerja keras mereka. (Pieris, 1994).

Dalam situasi yang sedang dihadapi Yesus, menurut Hurtado, gambaran seorang petani dapat dikatakan sebagai gambaran dari kehidupan yang prihatin, karena mereka seringkali hidup tanpa penghargaan. Kehidupan pertanian mereka selalu ditentukan, baik dalam cara atau metode bertani, oleh para penguasa yang ada, dan ini menunjukkan bahwa dari segi budaya, budaya tani sedang disingkirkan. (Hurtado 2011). Dalam situasi inilah Yesus mulai mengambil peran sebagai seorang petani. Yesus dengan sengaja mengindentifikasi diri sebagai 
petani agar seluruh petani dapat menemukan kekuatan dalam diri Yesus yang adalah seorang petani. Dengan tindakan-tindakan yang sangat memahami keberadaan alam (musim), tanah dan cara-cara bertani yang benar, Yesus mulai mengajarkan bagaimana bertani dengan bijak dan benar. Penghargaan terhadap tanah, kehidupan dan alam semesta (bdk. perkataan Yesus tentang tanah yang harus dipelihara, bunga bakung dan burung pipit) telah membuka mata hati manusia untuk bisa mengupayakan kehidupan bagi alam semesta. Pengupayaan terhadap alam bertujuan untuk menumbuhkembangkan kehidupan, bukan mengupayakan kematian. Jika pengupayaan itu berdampak pada kematian, entah melalui eksploitasi dan penggunaan bahan yang merusak unsur tanah, maka hal itu harus dihentikan.

Apa yang dilakukan oleh Yesus sebagai seorang petani menunjukkan bahwa model pertanian yang harus dikembangkan adalah tindakan bertani yang berpihak pada kehidupan, yang berdampak positif pada manusia dan seluruh alam semesta. Ini mengimplikasikan bahwa setiap bentuk pertanian yang menggunakan bahan pemunah bagi kehidupan yang dampaknya mematikan unsur kehidupan dalam tanah harus dihentikan dan tidak dilanjutkan. Manusia harus berpihak pada kehidupan alam semesta sehingga penggunaan pestisida perlu untuk dipertimbangkan ulang. Inilah yang mendorong terbentuknya kegiatan pertanian organik, karena bentuk pertanian organik ini adalah bentuk dari teologi pertanian yang berpihak pada kehidupan. Semua ini diinspirasikan oleh Yesus yang hidup sebagai seorang petani. 
Pedoman pertanian organik yang diteladankan Yesus bermuara pada kehendak Allah di dalam diri Yesus. Allah yang menciptakan alam dan meletakkan manusia di dalamnya supaya manusia memelihata alam. Dalam pemahaman ini dapat dikatakan bahwa petani terlibat bersama Allah dalam proses penciptaan. Petani, bersama Allah, terlibat bersama dalam proses membuat serta mengembangkan sebutir padi menjadi ratusan bulir padi, sehingga manusia bisa makan. Pertanian organik melihat bahwa Allah telah mengatur alam sehingga mengusahakan pertanian organik sangat berkaitan dengan posisi petani sebagai makhluk ciptaan yang setara dan hormat terhadap ciptaan yang lain; bahkan kepada Penciptanya. Oleh karena itu tujuan pertanian organik sebenarnya adalah untuk mewujudkan ide Sang Pencipta sebagai titik awal dan titik akhir dari segalanya agar dunia menjadi tempat yang aman, damai dan harmonis bagi seluruh ciptaan.

\section{Membangun Teologi Pertanian Kontekstual melalui Pembacaan Lintas Tekstual}

Jika teks-teks yang ada dalam Injil Matius dibaca secara lintas tekstual dengan kearifan kosmologis dalam budaya Jawa akan dijumpai bahwa sesungguhnya tindakan Yesus yang berpihak pada model pertanian yang menghargai alam dan kehidupan merupakan bentuk pengamalan belas kasih Allah untuk mewujudkan keadilan bagi kehidupan yang universal. Wujud nyata dari belas kasih kosmik ini ada dalam bentuk penghargaan terhadap alam melalui pemahaman bahwa dirinya adalah bagian dari alam dan ini senada dengan kearifan kosmologis dalam budaya Jawa. Budaya Jawa sangat menekankan kesatuan seluruh ciptaan, dan dalam kesatuannya dengan alam, manusia akan 
menjadi berkat terhadap seluruh ciptaan, Hal ini melahirkan paham integral bahwa bumi adalah rumah bersama yang diciptakan Allah (Kej. 1). Teologi pertanian kontekstual berangkat dari pemahaman bahwa Yesus adalah seorang petani yang akan menjaga keberlangsungan hidup tanah dan mengutus manusia untuk mandataris-Nya dalam menjaga keharmonisan alam.

Tindakan Yesus yang menjaga kehidupan alam merupakan wujud nyata dari tindakan Allah dalam menjaga taman Eden, yang secara harfiah berarti: kemakmuran atau kebahagiaan, sebagai sebuah kebun pertanian. Dalam menjaga taman Eden Allah melibatkan manusia dengan penekanan bahwa manusia adalah bagian dari Eden itu sendiri, dan sikap ini akan menjadikan taman Eden subur dan seimbang. Pertanian yang dilakukan manusia di taman Eden dalam bentuk menjaga kehidupan alam semesta, merupakan bentuk dari tindakan Allah sendiri (Kej. 2:8-9). Allah memelihara taman Eden melalui manusia, dengan cara mengupayakan dan melestarikan tanah karena manusia berasal dari tanah (Kej. 2:7). Hal ini memperlihatkan bahwa kemuliaan pertanian untuk merawat bumi merupakan teladan langsung dari Allah. Bagi Singgih, pengelolaan pertanian yang didasari oleh tanggung jawab memelihara bumi menunjukkan etos kedisiplinan yang harus dimiliki setiap manusia, sebagai mitra Allah, dalam memelihara taman Eden, yang merupakan representasi dari bumi. Oleh sebab itu, manusia harus bertani sesuai dengan tertib ilahi untuk kemakmuran segenap makhluk. (Singgih, 2011).

Menurut Akkeren, tindakan untuk menjaga alam melalui pertanian organik sudah menjadi pesan yang begitu kental dalam kehidupan masyarakat Jawa, yang 
memandang bahwa bertani bukan sekadar tindakan pekerjaan melainkan juga merupakan tindakan ritual yang hendak melestarikan alam. Itulah sebabnya setiap tindakan pertanian senantiasa didahului dan diakhiri dengan ritual/ibadah di lokasi pertanian. (Akkeren 1970). Tindakan ini hendak menunjukkan bahwa manusia yang menggarap tanah adalah pribadi yang akan bertanggung jawab terhadap kesejahteraan tanah. Tindakan manusia ini sekaligus menunjukkan tanggung jawab ilahi dalam menjaga kelestarian hidup dalam alam semesta, yang senada dengan apa yang telah dilakukan oleh Yesus.

Selanjutnya, Allah meminta agar manusia menjaga ketertiban ekologis melalui pertanian yang berpihak pada alam, manusia tidak boleh melanggar tata tertib ilahi agar tidak terjadi kekacauan. Pertanian harus menghadirkan ketertiban dan keadilan yang universal untuk menghasilkan kebaikan bagi seluruh kehidupan yang ada di muka bumi ini. Menurut Panjaitan dan Lumingkewas, kisah taman Eden meneguhkan bahwa Allah dan manusia, sebagai seorang petani, akan membela kelestarian ekologi dan kehidupan dunia. (Panjaitan dan Lumingkewas 2019). Gambaran Allah sebagai petani direpresentasikan langsung melalui kehidupan Yesus, yang senantiasa berpihak pada alam semesta bagi berkembangnya kehidupan yang sangat dihargai-Nya. Melalui tindakan-Nya sebagai petani, Yesus menunjukkan keberpihakan-Nya terhadap kehidupan, karena kehidupan itu merupakan unsur terpenting rencana Allah dalam penciptaan. Hal ini yang juga dihidupkan dalam model kehidupan pertanian masyarakat Jawa yang selalu berupaya berpihak pada kehidupan alam semesta sehingga keseimbangan hidup kosmik dapat terjaga dengan baik. Bumi adalah 
rumah bagi setiap makhluk hidup, sehingga segala bentuk tindakan yang berkaitan dengan bumi, khususnya pertanian, harus menjadi sarana yang menjaga kehidupan di bumi.

\section{KESIMPULAN}

Teologi pertanian kontekstual adalah bentuk praktik pertanian yang menjaga kelestarian alam semesta. Dalam teologi pertanian ini manusia didorong untuk menyadari bahwa dirinya adalah bagian dari alam, karena keduanya adalah ciptaan Allah, dan Allah mempercayakan upaya pelestarian alam kepada manusia. Hal inilah yang menjadi tekanan utama dalam keteladanan Yesus melalui praktik pertanian di jaman-Nya yang memiliki kesejajaran dengan kearifan kosmologis dalam budaya Jawa. Manusia adalah bagian dari alam dan harus mengupayakan kelestarian alam, oleh sebab itu manusia harus bersikap altruis (meletakkan kepentingan orang lain, termasuk alam semesta, sebagai orientasi tindakan) dalam hidup yang dipercayakan Allah. Setiap aktivitas kehidupan manusia harus menjaga dan melestarikan kehidupan seluruh ciptaan.

Teologi pertanian kontekstual tidak memperkenankan manusia merusak ciptaan Allah dengan cara bertani yang tidak menghargai alam, khususnya dengan cara membiarkan tanah menyerap setiap racun pupuk dan pestisida yang ditebarkan oleh manusia. Cara hidup altruis mendorong manusia untuk mendengar suara Alam, sehingga kebersatuannya dengan alam semesta dapat terjaga. Teologi pertanian kontekstual ini juga membuka kesadaran manusia bahwa alam adalah saudara sekaligus rumah bersama antara manusia dan seluruh makhluk hidup yang ada. Dalam kesadaran ini, menurut Singgih, manusia dapat 
melihat bahwa semua makhluk hidup memiliki kesamaan hakiki, yaitu sebagai makhluk ciptaan Allah yang begitu berharga. (Singgih, 1997). Karena alam semesta adalah saudara bagi manusia, maka alam dan manusia akan saling menjaga dan melindungi, karena keduanya diikat oleh cinta kasih.

Teologi pertanian kontekstual menciptakan suasana baru mengenai relasi antara manusia dengan Allah dan alam semesta. Masing-masing tidak lagi berada dalam keterpisahan, melainkan telah menyatukan diri dan meleburkan diri menjadi satu. Allah menyatakan diriNya di dalam alam sekaligus di dalam diri manusia, demikian juga alam akan menyatakan dirinya di dalam diri manusia. Sehingga teologi ini akan mendorong setiap manusia untuk membangun pertanian yang tidak akan mencemarkan alam melalui penggunaan pupuk kimia dan pestisida yang tidak bertanggung jawab. Teologi pertanian kontekstual mendorong manusia untuk bertani dengan tidak hanya memikirkan keuntungan pribadi, melainkan akan mengupayakan keuntungan dan kesejahteraan bagi alam. Dalam teologi ini manusia sadar bahwa dirinya bergantung kepada alam dan alam tergantung kepada manusia. Keduanya berada dalam rantai kehidupan yang saling mengisi satu sama lain, sehingga upaya untuk menyakiti satu sama lain tidak ada pernah terbersit dalam pikiran masing-masing pihak

\section{DAFTAR PUSTAKA}

Akkeren, Philip van. 1970. Sri and Christ: A Study of Indigenous Church In East Java. London: Lutterworth.

Andang, Al. 1998. Agama Yang Berpijak dan Berpihak. Yogyakarta: Kanisius.

Brata, Sumadi Surya. 2002. Metodologi Penelitian. Jakarta: Raja Grafindo Persada. 
Dewi, Novita. 2015. "Manusia dan Lingkungannya dalam Cerpen Indonesia Kontemporer: Analisis Ekokritik Cerpen Pilihan Kompas.” Jurnal Litera 14 (2): 388-89.

Draper, Richard D. 1987. "The Parables of Jesus.” In Studies in Scripture, diedit oleh Kent P. Jackson dan Robert L. Millet, V. Salt Lake-Utah: Deseret Book Company.

Endraswara, Suwardi. 2018. Mistik Kejawen: Sinkretisme, Simbolisme dan Sufisme dalam Budaya Spiritual Jawa. Yogyakarta: Narasi.

Fadillah, Hernawan Luthfi. 2019. “Adanya Moderniasi pada Pertanian, Menguntungkan Petani atau Malah Merugikan?” Kompasiana, 2019.

Gensichen, D H W. 2000. Perang dan Perdamaian dalam Agama. Diedit oleh Zama, Ali Noer, dan Agama Manusia. Yogyakarta: Pustaka Pelajar.

Hartati, Anna Yulia. 2012. "Global Environmental Regime: Di Tengah Perdebatan Paham Antroposentris Versus Ekosentris." Spektrum: Jurnal Ilmu Politik Hubungan Internasional 12 (1): 1-2.

Harun, Martin. 2015. Ensiklik Laudato Si': Tentang Perawatan Rumah Kita Bersama, Karya Paus Fransiskus. Surabaya: Komisi Pengembangan Sosial Ekonomi Keuskupan Surabaya.

Horrel, David G. 2009. "The Ecological Challenge to Bible Studies", Theology 112 (2009): 163.” Theology 112.

Hurtado, Larry W. 2011. Jesus Among Friends and Enemies. Diedit oleh Chris Keith. Michigan: Baker Academic.

Ituma, Ezichi A. 2013. "Christocentric Ecotheology and Climate Change." Open Journal of Philosophy 3 (1A): 126.

Jr., Lynn White. 1974. "The Historical Roots of Our Ecological Crisis." In Ecologi and Religion in History, diedit oleh David and Eileen Spring. New York, Evanston, San Fransisco, London: Harper \& Row.

Lee, Archie. 1998. "Cross-textual Interpretation and Its Implications for Biblical Studies." In Teaching the Bible, The Discourses and Politics of Biblical Pedagogy, diedit oleh Fernando Segovia and Mary Ann Tolbert. New York: Orbis Books.

Magnis-Suseno, Franz. 1997. Javanese Ethics and World View. Jakarta: PT Gramedia Pustaka Utama.

Natar, Asnath Niwa. 2019. "“Penciptaan Dalam Perspektif Sumba: Suatu Upaya Berteologi Ekologi Kontekstual."” Jurnal Gema Teologika 4 (1): 100. 
Panjaitan, Firman. 2003. Teologi Mistik sebagai Jalan Kehidupan: Membangun Teologi Mistik Kontekstual Indonesia melalui Perbandingan Pengalaman Mistik Paulus dalam 2 Korintus 12: 1-10 dengan Pengalaman Mistik Bima dalam kisah Dewa Ruci. OSF Preprints.

. 2005. "Spiritualitas Mistik Sebagai Jalan Kesadaran: Tawaran untuk Membangun Teologi Mistik Protestan." Studia Philosphica et Theologica 5 (1): 99-117.

_. 2011. "Harmonisasi dalam Ekologi Manusia.” Ikhtus 1 (1).

Panjaitan, Firman, dan Marthin S. Lumingkewas. 2019. "Keadilan Dalam Hukum Lex Talionis: Tafsir Terhadap Keluaran 21:22-25." Pengarah: Jurnal Teologi Kristen 1 (2): 73-84. https://doi.org/10.36270/pengarah.v1i2.13.

Pieris, Aloysius. 1994. "Inculturation in Asia. A theological reflection on an experience"." Jahrbuch für Kontextuelle Theologien 94.

Raphael, Melissa. 2016. "The creation of beauty by its destruction: the idoloclastic aesthetic in modern and contemporary Jewish art." Journal Approaching Religion 6 (2).

Singgih, Emanuel Gerrit. 1997. Reformasi dan Transformasi Pelayanan Gereja Menyosong Abad ke-21. Yogyakarta: Kanisius.

—. 1999. Dunia yang Bermakna. Jakarta: Persetia.

- 2011. Dari Eden ke Babel: Sebuah Tafsir Kejadian 1-11. Yogyakarta: PPST UKDW.

Soemardi. 2019. "Wawancara."

Takenaka, Masao. 1986. God is Rice: Asian Culture and Christian Faith. Genewa: World Council of Churches.

Theissen, Gerd. 2005. Gerakan Yesus. Maumere: Penerbit Ledalero.

Vale, Matt. 1995. Siapa yang Tinggal Di Rumah Seperti Ini. UK Petra + The Hanns Siedel Foundation.

Widijanto, Tjahjono. 2018. "Dunia Halus Mistis Jawa dan Fantasi Magis Ternate dalam Godlob dan Cala Ibi.” Jentera: Jurnal Kajian Sastra 7 (1): 110-12.

Wijaya, Wawuk Kristian. 2011. "Allah Sang Petani, Bertani sebagai Usaha Berteologi: Belajar dari YBSB dan SPTN HPS.” Gema Teologi 35 (1). 